\title{
The Effect of Work Environment on Work Satisfaction Among PWC Indonesia Employees with Motivation as Mediating Variable
}

\author{
Herlina Budiono ${ }^{1}$, Oey Hannes Widjaya ${ }^{1}$, Jonnardi Jonnardi ${ }^{1}$, Isabella Jasmine ${ }^{1}$ \\ ${ }^{1}$ Faculty of Economics \& Business, Universitas Tarumanagara, West Jakarta 11440, Indonesia \\ "Corresponding author. Email: herlinab@fe.untar.ac.id
}

\begin{abstract}
Job satisfaction is one of the factors that influence employee productivity. The work situation in the company will affect the job satisfaction of an employee. Employees who are satisfied with their work will be more loyal to the company because they think that the company has succeeded in fulfilling the desire of employees in the context of work. This study raises the effect of work environment on employee job satisfaction with motivation as mediation of $115 \mathrm{PwC}$ Indonesia's employees using purposive sampling method and proceed using PLSSEM. The result showed that the work environment has a significant effect on job satisfaction, the work environment has a significant influence on motivation, motivation has a significant effect on job satisfaction, the work environment has a significant effect on job satisfaction with motivation as a mediating variable.
\end{abstract}

\section{Keywords: Work Environment, Job Satisfaction, Motivation}

\section{INTRODUCTION}

In this era of globalization, companies must be able to survive in the midle of increasingly fierce business competition. Every company must have good management, so that the company can develop according to the times, the company must improve the quality of its human resources. Human resources are believed to be one of the driving factors so that all elements in a company can run well. Job satisfaction is one of the factors that affect employee productivity. According to [1] a feeling that supports or does not support employees at work is job satisfaction. The work situation that exists in the company will affect the job satisfaction of an employee.

Job satisfaction felt by employees is a feeling of pleasure or displeasure, comfortable or uncomfortable with the work environment of the company where they work. Employee job satisfaction is dynamic, which means it can change at any time. Employees will feel satisfied with their work if both aspects of their work and themselves support each other, otherwise employees will be dissatisfied with their work.

Employees who are satisfied with their work will be more loyal to the company because employees think that the company has succeeded in fulfilling their desires in the context of work. Employee loyalty can be manifested in the form of always visible work spirit, high work discipline, and work morale that they have in carrying out their duties and responsibilities at work.

The work environment that affects employee job satisfaction consists of two, namely the physical work environment and the non-physical work environment.
According to [2] all situations around the workplace, which affect employees either directly or indirectly, are physical work environments. Meanwhile, all events that occur and are related to the work relationship of employees both with superiors and subordinates are a non-physical work environment.

Another factor that affects employee job satisfaction is motivation. According to [3] the process that begins with a physiological or psychological definition that drives behavior or impulses aimed at goals or incentives is motivation. Motivation is used as a basis and a trigger for someone to be able to do something as much as possible. If someone does not have high motivation in himself to do something, then he will do it half-heartedly and not try to give his best [4].

Based on this background, the formulation of the problem can be raised, among others, does the work environment have an influence on job satisfaction? Does motivation have an influence on job satisfaction? Does the work environment have an influence on motivation? Does the work environment have an influence on employee job satisfaction with motivation as mediation?

\section{RESEARCH METHOD}

This study uses a comparative causal method, which according to [5] means a comparison between two groups or more of a certain variable. The data collected in this study are primary data obtained from distributing questionnaires to $\mathrm{PwC}$ Indonesia employees in Jakarta. The population in this study were all employees of PwC Indonesia in the audit division who were in Jakarta. 
The sample selection technique used in this study refers to [6], namely the Slovin formula. The Slovin formula is used to determine the sample size of a known population, here is the formula used:

According to [6] the tolerable error limit used in the study is $10 \%$. It is known that the number of PwC Indonesia employees in the audit division in Jakarta is 200 people. Then the number of samples can be obtained in the following way:

$$
\begin{gathered}
n=\frac{200}{1+200\left(0_{s} 1\right)^{2}} \\
n=66,6667=67 \text { samples }
\end{gathered}
$$

The number of samples obtained from the calculation of the Slovin formula above is 67 respondents. Thus the number of respondents has exceeded the minimum requirements of 30 respondents who are considered close to the normal distribution, where the larger the sample (number of respondents) taken, the more accurate results are based on what [7] stated.

This study uses PLS-SEM for data analysis. PLS is a powerful analytical method because it is not based on many assumptions, for example the data does not have to be normally distributed, the sample does not have to be large [8].

The research model used in this study is as follows:

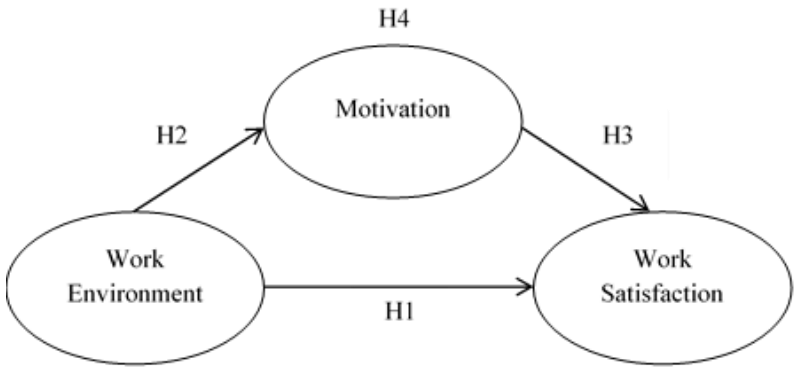

Figure 1. Research Model

Based on this research model, the following hypotheses can be formulated:

$\mathrm{H}_{1}$ : The work environment has a significant influence on job satisfaction.

$\mathrm{H}_{2}$ : The work environment has a significant influence on motivation.

$\mathrm{H}_{3}$ : Motivation has a significant effect on job satisfaction.

$\mathrm{H}_{4}$ : The work environment has a significant influence on job satisfaction with motivation as a mediating variable.

\section{RESULT AND DISCUSSION}

Based on the results of the questionnaire obtained from 115 respondents that can be used, the characteristics of each respondent can be classified based on gender, age, last education and length of work at the company. Questionnaire respondents based on gender. Of the 115 respondents who filled out the questionnaire, 73 respondents $(63.50 \%)$ were male and the remaining 42 respondents $(36.50 \%)$ were women. Classification of respondents based on age, where the age of the respondents is categorized into 5 groups, namely 82 respondents $(71.30 \%)$ aged $21-25$ years, 13 other respondents (11.30\%) aged 26-30 years, then 15 respondents $(13.04 \%)$ aged 31-35 years, and 5 respondents $(4.35 \%)$ were over 35 years old. Of the 115 respondents, 21 respondents $(18.26 \%)$ had the latest SMA / equivalent education level, then 83 respondents $(72.17 \%)$ had the latest Bachelor's education (S1), then there were 7 respondents $(6.09 \%)$ the last education was Masters (S2), there were also 3 respondents $(2.61 \%)$ who had the latest education as a Doctor (S3). And finally, in terms of the last education they had, there was 1 respondent who chose the "other" option on the questionnaire and filled out a Diploma or D3 as the last education he had $(0.87 \%)$. Meanwhile, the percentage of respondents based on the length of work at PwC Indonesia in Jakarta is in the audit department. Of the 115 respondents, there were 23 respondents (20\%) who worked less than 1 year, then there were 72 respondents $(62.61 \%)$ who had worked for 1-5 years, there were also 15 respondents $(13.04 \%)$ who worked for 6-10 years, and finally there are 5 respondents $(4.35 \%)$ who have worked for more than 10 years.

The results of the validity test in this study used Convergent Validity which is a measurement instrument that can be seen from the value of the Average Variance Extracted (AVE) and the Loading Factor. According to [9], convergent validity is indicated by a loading factor value greater than 0.50 (loading factor> 0.5 ).

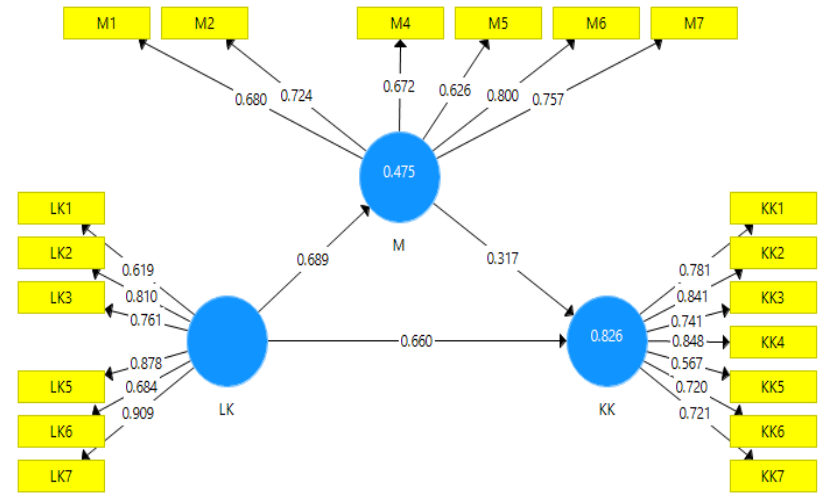

Figure 2. Analysis Result of PLS Algorithm Source: Result of PLS Data Processing

Table 1. Average Variance Extracted (AVE)

\begin{tabular}{|c|c|}
\hline Variable & AVE \\
\hline Work Environment & $\mathbf{0 , 3 1 4}$ \\
\hline Motivation & $\mathbf{0 , 5 0 7}$ \\
\hline Work Satisfaction & $\mathbf{0 , 5 6 3}$ \\
\hline
\end{tabular}

Source: Result of PLS Data Processing 
Table 1 shows that the value of the existing indicators has a loading factor value above 0.5 and the table shows that the AVE value of each variable is above 0.5. Based on Figure 2 , the indicators used in this study are valid or have met the minimum requirements of convergent validity.

The reliability test according to [9] states that if the Cronbach's alpha value is greater than 0.6 (Cronbach's $\alpha \geq$ $0.6)$ and the composite reliability value is greater than 0.7 $(C R \geq 0.7)$ then the instrument reliability has fulfilled.

Table 2. Composite Reliability and Cronbach's Alpha

\begin{tabular}{|c|c|c|}
\hline Variable & $\begin{array}{c}\text { Composite } \\
\text { Reliability }\end{array}$ & $\begin{array}{c}\text { Cronbach's } \\
\text { Alpha }\end{array}$ \\
\hline $\begin{array}{c}\text { Work } \\
\text { Environment }\end{array}$ & 0.904 & 0.870 \\
\hline Motivation & 0.860 & 0.804 \\
\hline $\begin{array}{c}\text { Work } \\
\text { Satisfaction }\end{array}$ & 0.899 & 0.868 \\
\hline
\end{tabular}

Source: Result of PLS Data Processing

The values of Composite Reliability and Cronbach's Alpha have been shown in table 2, the indicators used have a Composite Reliability value of $\geq 0.6$ and a Cronbach's Alpha value $\geq 0.6$. From the table above, it can be stated that the indicators used have passed the reliability test. To show the relationship between one variable and other variables in this study is the aim of conducting Path Coefficients analysis. Through the PLS Algorithm method, the path coefficients were obtained. Meanwhile t-statistics and p-values can be obtained using the bootstrapping method.

Table 3. Bootstrapping and PLS Algorithm

\begin{tabular}{|c|c|c|c|c|c|c|}
\hline \multirow{2}{*}{ Variable } & \multicolumn{3}{|c|}{ Motivation } & \multicolumn{3}{c|}{ Work Satisfaction } \\
\cline { 2 - 7 } & $\begin{array}{c}\text { Path } \\
\text { Coefficients }\end{array}$ & $\mathbf{t}$-statistics & p-values & $\begin{array}{c}\text { Path } \\
\text { Coefficien } \\
\text { ts }\end{array}$ & t-statistics & p-values \\
\hline $\begin{array}{c}\text { Work } \\
\text { Environment }\end{array}$ & 0.689 & 13.279 & 0.000 & 0.660 & 9.739 & 0.000 \\
\hline Motivation & & & & 0.317 & 3.848 & 0.000 \\
\hline
\end{tabular}

Source: Result of PLS Data Processing

The value of path coefficients (path coefficients), t-statistics and $\mathrm{p}$-value for each independent variable on the dependent variable and the mediating variable are generated by the PLS Algorithm method. In this study, the mediating variable and the dependent variable are positively influenced by the independent variable. Work environment variable is a positive influence on motivation with a value of 0.689. Meanwhile, the work environment variable also plays a role as a positive influence on job satisfaction with a value of 0.660 . The work motivation variable is a positive predictor of the job satisfaction variable with a value of 0.317 . Thus, the following equation is formed for this study: $\mathrm{M}=0.689 \mathrm{LK}$ and $\mathrm{KK}=0.660 \mathrm{LK}+0.317 \mathrm{M}$.

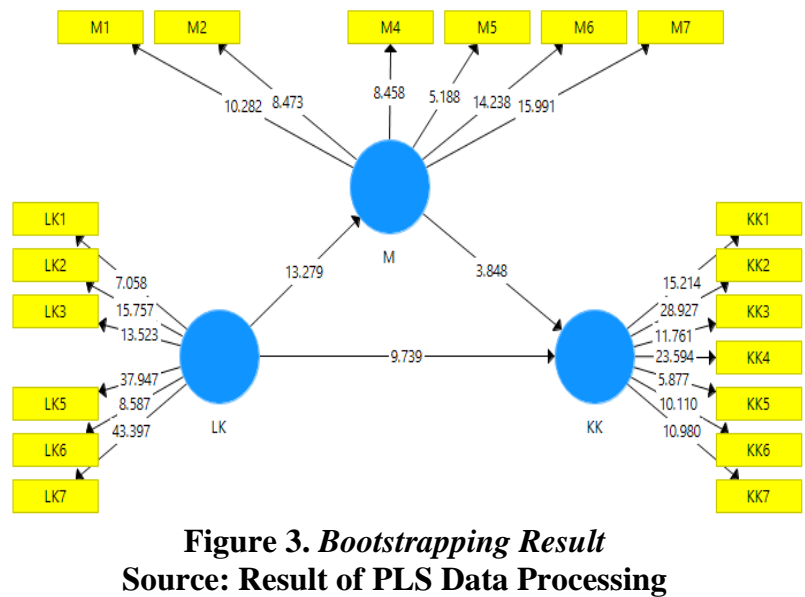

To test the hypothesis of a study, where the research hypothesis can be accepted if the t-statistics variable value is above 1.96 (5\% significance level) and the p-value is less than the cut-off value $(5 \%)$ is the goal of knowing the tstatistics value. The t-statistics and p-value of each hypothesis in this study are shown in Table 3 (Bootstrapping Results).

The first hypothesis which states that "the work environment has a significant influence on job satisfaction" is not rejected. Thus, it can be concluded that the work environment has a significant effect on job satisfaction. In measuring the work environment, the indicators that have the greatest influence are "good air sources (air circulation) in the office" in the physical work environment and "good communication between subordinates and superiors" in the non-physical work environment.

This shows that in order to improve the work environment, there must be a good source of air (air circulation) so that employees can work comfortably and there is good communication between subordinates and superiors so that employees feel comfortable at work and do not hesitate to ask questions or chat with superiors. A source of air (air circulation) is what is needed in an office so that working conditions in the office are comfortable and do not interfere with employee activities.

The establishment of good communication between subordinates and superiors is also important because without good communication, employees will feel afraid of their superiors and hesitate to ask questions. Whereas employees who rarely ask their superiors about their work will find it difficult to get progress in their careers, because they do not get knowledge of new things or motivation to work. Smooth communication with superiors can make the employee's mood better.

So, it can be concluded that the better the orientation of the work environment, the more satisfied employees will be with their work. As for the measurement of the work environment, the smallest indicator is LK1 or "the air temperature in the office is quite good (comfortable)". Less air temperature will create uncomfortable working conditions which can interfere with someone's work and can reduce their satisfaction with the job. The results of this 
study are in accordance with the results of previous studies conducted by $[10,11,12]$ which state that the work environment has a significant influence on job satisfaction. This study also has results that are inconsistent with research conducted by [13] where the work environment does not have a significant effect on employee job satisfaction

The second hypothesis which states that "the work environment has a significant influence on motivation" is also not rejected. Thus, it can be concluded that the work environment variable has a significant influence on motivation. In measuring the work environment on motivation, the indicators that have the greatest influence are "good air sources (air circulation) in the office" in the physical work environment and "good communication between subordinates and superiors" in the non-physical work environment. By having a good air source (air circulation) in the office and making conditions in the office comfortable, employees will automatically be motivated to work well because they are supported by a comfortable environment.

The existence of smooth communication between subordinates and superiors also motivates employees to do their work because they feel that they are recognized and appreciated by their superiors. Recognized and appreciated by superiors manifested from input from employees who are considered or even implemented, questions that are always responded to by superiors, employee successes are acknowledged by superiors, and others. Thus, a good work environment will motivate employees to do their jobs. The work environment indicator that has the smallest influence on motivation is "the temperature in the office is good enough (comfortable)". The absence of a good temperature can reduce the work motivation of an employee. The results of this study are consistent with previous studies conducted by $[14,15,16]$ who state that the work environment has a significant influence on motivation.

The next hypothesis is the third hypothesis which states that "motivation has a significant effect on job satisfaction" is not rejected. Thus, it can be concluded that motivation has a significant effect on job satisfaction. In measuring motivation, the indicator that has the greatest influence is "employees accept responsibility or have better opportunities for development".

Employees who are trusted by their place of work, in this case a Public Accounting Firm (KAP), can increase their level of confidence and feel proud of their work. Employees are given jobs that are new to them every day and make them feel needed by the office where they work. Employees who are also given the opportunity to develop and become better feel, that they allowed to have more abilities than they have now. These things that motivate employees to do their jobs and produce a sense of satisfaction at work.

The motivation indicator that has the smallest influence on job satisfaction is M6 or "employees accept responsibility or better opportunities for development". The closure of opportunities for development at work can make employees not enthusiastic about working, thereby reducing job satisfaction. The results of this study are in accordance with previous studies conducted by $[17,18,19]$ which state that motivation has a positive and significant effect on job satisfaction. However, this study also has different results from research conducted by [13] and [20] where motivation does not have a significant effect on job satisfaction.

The fourth hypothesis as the final hypothesis which states that "the work environment has a significant influence on job satisfaction with motivation as a mediating variable" is also not rejected. From the indicators "there is a good air source (air circulation) in the office" in the physical work environment and "good communication between subordinates and superiors" in the non-physical work environment and the indicator "employees accept responsibility or more opportunities for development "good" in the Motivation variable, it can be concluded that the existence of a comfortable work environment will motivate employees to do their job well, as well as achieve job satisfaction. In addition, with the motivation to do work, employees will feel satisfied with their work.

The smallest indicator of work environment variables that affect job satisfaction is "the temperature in the office is quite good (comfortable)". Office conditions must be made as comfortable as possible for employees, one of which is a good temperature to increase employee satisfaction with their work. The work environment indicator that has the smallest influence on motivation is "the temperature in the office is good enough (comfortable)". Likewise, bad air temperatures can reduce employee morale at work because working conditions are not as expected. The motivation indicator that has the smallest influence on job satisfaction is "employees accept responsibility or have better opportunities for development". Responsibilities and opportunities for growth are employee motivation to work and improve careers to achieve job satisfaction and welfare. Motivation in this study acts as a partial mediation between the variables of the Work Environment and Job Satisfaction, which means that with partial motivation between the work environment and job satisfaction, employees who have a good work environment and are supported by motivation to do their jobs can get satisfaction. work.

\section{CONCLUSION AND SUGGESTION}

Based on the data analysis and discussion that has been done, the results of this study can be concluded as follows: The work environment has a significant influence on job satisfaction. The work environment has a significant influence on motivation. Motivation has a significant effect on job satisfaction. The work environment has a significant influence on job satisfaction with motivation as partial mediation.

In connection with the results obtained in this study with all its limitations, the following suggestions can be given to the next researchers, it is suggested to increase the number of samples and expand the sampling range in order to improve and strengthen previous studies with the diversity in the characteristics of the research samples. For the next researcher, it is suggested to include other variables in the study such as compensation, organizational culture, 
turnover intention, organizational citizenship behavior, and other variables.

\section{REFERENCES}

[1] Mangkunegara, A.P., Manajemen Sumber Daya Manusia Perusahaan, Bandung, PT. Remaja Rosdakarya, 2015.

[2] Sedarmayanti, Sumber Daya Manusia dan Produktivitas Kerja, Bandung, Mandar Maju, 2009.

[3] Luthans, F., Perilaku Organisasi, Edisi Sepuluh, Yogyakarta, ANDI, 2011.

[4] Armstrong, M., Managing People, alih bahasa Ramelan dan Dwi Prabaningtyas, Jakarta, PT. Gramedia, 2013.

[5] Arifin, Z., Penelitian Pendidikan Metode dan Paradigma Baru. Bandung: Remaja Rosda Karya, 2012.

[6] Kriyantono, R., Teknik Praktis Riset Komunikasi, Jakarta, Kencana Prenada Media Group, 2006.

[7] Supranto, J., Metode Riset dan Aplikasinya dalam Pemasaran, Jakarta, PT. RINEKA CIPTA, 2012.

[8] Irwan., Adam, K., Metode Partial Least Square (PLS) dan Terapannya (Studi Kasus: Analisis Kepuasan Pelanggan terhadap Layanan PDAM Unit Camming Kab. Bone), Teknosains: Media Informasi Sains dan Teknologi, 2015, 9(1), pp. 53-68. DOI: https://doi.org/10.24252/teknosains.v9i1.1856

[9] Abdillah, W., Jogiyanto, Partial Least Square (PLS) Alternatif Structural Equation Modeling (SEM) dalam Penelitian Bisnis, Ed.1, Yogyakarta, ANDI, 2015.

[10] Sitinjak, L.N., Pengaruh Lingkungan Kerja Terhadap Kepuasan Kerja Karyawan Studi Kasus pada Karyawan PT. Mitra Pinasthika Musthika Rent Tangerang Selatan, Jurnal Administrasi Bisnis (JAB), 2018, 60(2), pp. 162-168.

[11] Wibowo, M., Musadieq, M.A., Nurtjahjono, G.E., Pengaruh Lingkungan Kerja Terhadap Kepuasan Kerja Karyawan pada Karyawan PT. Telekomunikasi Indonesia Tbk. Kandatel Malang, Jurnal Administrasi Bisnis (JAB), 2014, 16(1), pp. 1-9.

[12] Pawirosumarto, S., Sarjana P.K., Gunawan, R., The Effect of Work Environment, Leadership Style, and Organizational Culture towards Job Satisfaction and Its Implication towards Employee Performance in Parador Hotels and Resorts Indonesia, International Journal of
Law and Management, 2016, 59 (6), pp. 1337-1358. DOI: https://doi.org/10.1108/IJLMA-10-2016-0085

[13] Afiyah, S., Djaelani, A.Q., Priyono, A.A., Pengaruh Kompensasi, Lingkungan Kerja, dan Motivasi Terhadap Kepuasan Kerja Karyawan (Studi Kasus pada Badan Pertanahan Nasional Kabupaten Malang), Jurnal Ilmiah Riset Manajemen (eJRM), 2017, 6(2), pp. 328-341.

[14] Prakoso, R.D., Astuti, E.S., Ruhana, I., Pengaruh Lingkungan Kerja Terhadap Motivasi Kerja dan Kinerja Karyawan pada Karyawan PT. AXA Financial Indonesia Cabang Malang, Jurnal Administrasi Bisnis (JAB), 2014, 14(2), pp. 1-10.

[15] Rezita, R., Pengaruh Lingkungan Kerja terhadap Motivasi Kerja Karyawan di Bank Jatim Cabang Utama Surabaya, Jurnal Administrasi Perkantoran (JAP), 2014, 2(2), pp. 1-15.

[16] Ingsiyah, H., Haribowo, P., Nurkhayati, I., Pengaruh Lingkungan Kerja Terhadap Motivasi Kerja Karyawan pada PT. Pupuk Sriwidjaja Palembang, PUSRI Pemasaran Daerah (PPD) Jawa Tengah, Jurnal Politeknik Negeri Semarang (Polines), 2019, 20(1), pp. 83-91. DOI: http://dx.doi.org/10.32497/ab.v20i1.1428

[17] Astuti, H.D., Iskandar, D, Pengaruh Motivasi Terhadap Kepuasan Kerja Karyawan Studi Kasus pada PT. Chitose Internasional Tbk, E-Proceeding of Management, 2015, 2(2), pp. 1232-1238.

[18] Ananto, S., Rahyuda, I.K., Priartrini, P.S., Pengaruh Motivasi Terhadap Kepuasan Kerja dan Intensi Keluar pada Asisten Kursus Metode Kumon di Bali dan Lombok, E-Jurnal Ekonomi dan Bisnis Universitas Udayana, 2016, 5(9), pp. 3057-3085.

[19] Arinal, V., Rahayu, A.T., Pengaruh Motivasi dan Kompensasi Terhadap Kepuasan Kerja Dosen di Sekolah Tinggi Ilmu Komputer Cipta Karya Informatika, Jurnal CKI on SPoT, 2017, 10(1), 1-10.

[20] Ariani, Hj. M., Assarofa, A., Pengaruh Motivasi, Disiplin, dan Lingkungan Kerja Terhadap Kepuasan Kerja Karyawan: Studi Kasus pada PT. Palma Plantasindo di Desa Sunge Batu Kecamatan Pasir Belengkong Kabupaten Paser. Conference on Management and Behavioral Studies Universitas Tarumanagara, 2018, pp. 68-77. 